\title{
MODEL PROBLEM BASED LEARNING DENGAN PENDEKATAN SAINTIFIK TERHADAP KEMAMPUAN PEMECAHAN MASALAH MATEMATIS SISWA
}

\author{
Muhammad Agus Aprianto ${ }^{1}$, Rosmaiyadi ${ }^{2}$, Nindy Citroresmi Prihatiningtyas ${ }^{3}$ \\ Pendidikan Matematika, STKIP Singkawang, Singkawang, Indonesia \\ agusanto123.aa@gmail.com ${ }^{I}$, rosmaiyadialong@gmail.com $^{2}$, nindy.citroresmi@yahoo.com ${ }^{3}$
}

\begin{tabular}{ll}
\hline \hline Keywords : & ABSTRACT \\
Problem Based Learning; & Penelitian ini bertujuan untuk mengetahui pengaruh Model \\
Saintifik; kemampuan & Problem Based Learning dengan Pendekatan Saintifik Terhadap \\
pemecahan masalah; & Kemampuan Pemecahan Masalah Matematis Siswa, dan \\
motivasi belajar & notivasi belajar siswa pada materi perbandingan kelas VII SMP \\
& Vegeri 2 Singkawang. Penelitian ini menggunakan desain Quasi \\
& Eksperimental.Populasi dalam penelitian ini adalah semua kelas \\
& VII SMP Negeri 2 Singkawang yang terdiri dari lima kelas yang \\
berjumlah 160 siswa. Sampel diambil dengan teknik Cluster \\
Random Sampling. Adapun sampel yang dipilih terdiri dari dua \\
kelas yaitu kelas VIIE sebagai kelas eksperimen dan kelas VIIC \\
sebagai kelas kontrol. Hasil pengaruh model PBL dengan \\
nendekatan Saintifik menunjukkan: 1) Terdapat perbedaan \\
kemampuan pemecahan masalah matematis antara siswa yang \\
nendapatkan model pembelajaran Problem Based Learning \\
tengan Pendekatan Saintifik; dengan rata-rata hasil posttest \\
kelas ekperimen yaitu 81,34 2) Model pembelajaran Problem \\
Based Learning dengan Pendekatan Saintifik memberikan \\
Dengaruh yang tinggi terhadap kemampuan pemecahan masalah \\
natematis siswa pada materi perbandingan; dengan hasil uji \\
?ffect size sebesar 3,5 3) Motivasi belajar siswa tergolong \\
tinggi dengan diterapkannya model Problem Based Learning \\
tengan Pendekatan Saintifik dengan rata-rata keseluruhan \\
siswa adalah 4,16.
\end{tabular}




\section{INTRODUCTION}

Matematika merupakan salah satu mata pelajaran yang diajarkan secara bertahap dari konkrit menjadi abstrak dan secara berkesinambungan. Permendiknas nomor 22 tahun 2006 menyatakan bahwa "matematika merupakan ilmu universal yang mendasari perkembangan teknologi modern, mempunyai peran penting dalam mengembangkan daya pikir manusia dan salah satu mata pelajaran wajib". Untuk memecahkan persoalan matematika tersebut diperlukan kemampuan-kemampuan dasar yang harus dimiliki oleh para siswa agar dapat menghasilkan jawaban-jawaban yang tepat dan kesimpulan yang logis.

National Countil of Mathematichs (NCTM, 2000) menyatakan bahwa terdapat lima kemampuan dasar matematika yang merupakan standar proses bermatematika salah satunya yaitu kemampuan pemecahan masalah. Tujuan pembelajaran matematika bukan hanya mengalihkan pengetahuan matematika kepada siswa, tetapi juga mnegembangkan potensi yang ada pada siswa dan memiliki keterampilan pengetahuan tersebut sehingga memungkinkan terjadinya perubahan pada pola pikir siswa. untuk memastikan bahwa ia telah menentukan pilihan dan menarik kesimpulan yang tepat dan cerdas. 
Kemampuan pemecahan masalah sangat penting artinya bagi siswa dan masa depannya. Diantaranya pendapat Polya (1985) yang banyak dirujuk pemerhati matematika. Polya mengartikan pemecahan masalah sebagai suatu usaha mencari jalan keluar dari suatu kesulitan guna mencapai suatu tujuan yang tidak begitu segera dapat dicapai. Hal ini karena matematika bukan sekedar ilmu hitung menghitung, tetapi juga dapat digunakan untuk membuktikan kebenaran ide dan memecahkan masalah melalui cara berfikir yang logis dan terstruktur (Rosmaiyadi, 2018). Pemecahan masalah juga merupakan suatu hal yang sangat essensial dalam pengajaran matematika. Hal ini disebabkan karena(1) siswa menjadi terampil menyeleksi informasi yang relevan, kemudian menganalisanya dan akhirnya meneliti isinya; (2) kepuasan intelektual akan timbul dari dalam; (3) potensi intelektual siswa meningkat . Nindy (2016) mengatakan bahwa pemecahan masalah merupakan kompetensi strategi yang ditunjukan siswa dalam memahami, memilih pendekatan dan strategi pemecahan, dan menyelesaikan model untuk menyelesaikan masalah.

Visi pertama untuk kebutuhan masa kini, pembelajaran matematika mengarah pada pemahaman konsep-konsep yang diperlukan untuk menyelesaikan masalah matematika dan ilmu pengetahuan lain. Visi kedua untuk kebutuhan masa yang akan datang atau mengarah ke masa depan, mempunyai arti lebih luas, yaitu pembelajaran matematika memberikan kemampuan nalar yang logis, sistematis, kritis, dan cermat serta berpikir objektif dan terbuka, yang sangat diperlukan dalam kehidupan sehari-hari. Kemampuan berpikir melatih siswa untuk menyelesaikan masalah matematika dalam menarik kesimpulan serta menggunakan dalam kehidupan sehari-hari.

Namun pada kenyataannya kemampuan pemecahan masalah siswa masih rendah mereka belum baik dalam menyelesaikan masalah matematis yang berkaitan dengan soal pemecahan masalah

Kurangnya kemampuan pemecahan masalah matematis siswa dinyatakan dalam hasil penelitian yang dilakukan oleh Septian Wulandari, (2013) kemampuan pemecahan masalah siswa di kelas VII SMP Kemala Bhayangkari Sungai Raya berdasarkan kelompok atas termasuk dalam kategori rendah dengan persentase ketercapaian sebesar 56,25\%, untuk kelompok menengah termasuk dalam kategori sangat rendah dengan persentase ketercapaian sebesar 37,5\%, dan untuk kelompok bawah termasuk dalam kategori sangat rendah dengan persentase ketercapaian sebesar 22,08\%.

Berdasarkan wawancara yang dilakukan dengan guru matematika kelas VII di SMPN 2 Singkawang rendahnya kemampuan pemecahan masalah siswa dikarenakan siswa terkadang lamban dalam menganalisis masalah yang diberikan sehingga banyak waktu terbuang dalam mengerjakan soal yang diberikan dan siswa monoton dalam mengerjakan soal yang diberikan mereka hanya terfokus pada contoh yang diberikan guru, mereka sulit mengkreasi suatu permasalahan yang diberikan dan juga beliau mengatakan siswa menganggap pelajaran matematika itu pelajaran yang sulit hal ini mengakibatkan motivasi siswa pada pelajaran matematika rendah. Untuk itu diperlukannya sebuah model yang tepat untuk meningkatkan kemampuan pemecahan masalah matematis siswa yaitu dengan model Problem Based Learning dengan pendekatan saintifik.

Problem Based Learning siswa dituntut untuk melakukan pemecahan masalah-masalah yang disajikan dengan cara menggali informasi sebanyak-banyaknya. Pengalaman ini sangat diperlukan dalam kehidupan sehari-hari agar berkembangnya pola pikir dan pola kerja seseorang bergantung pada bagaimana dia membelajarkan dirinya. Pada intinya pembelajaran PBL merupakan suatu pembelajaran yang menggunakan masalah dunia nyata disajikan di awal pembelajaran (E Dwi Nur Qori'ah, 2015).Pendekatan saintifik adalah pendekatan yang digunakan dalam kurikulum 2013 dan pendekatan ini sangat sesuai dengan model $P B L$. Dan pendekatan saintifik ini dimaksudkan untuk memberikan pemahaman kepada siswa dalam mengenal, memahami berbagai materi menggunakan pendekatan ilmiah di mana informasi bisa berasal dari mana saja, kapan saja, apa saja dan siapa saja. Langkahlangkah pendekatan ilmiah (scientific appoach) dalam proses pembelajaran meliputi lima tahap yaitu mengamati, menanya, mencoba, menalar, dan mengkomunikasikan. 


\section{METHOD}

Jenis penelitian ini adalah jenis penelitian kuantitatif dengan metode eksperimen. Desain penelitian yang digunakan dalam penelitian ini adalah quasi-eksperimental design dengan rancangan nonequivalent posttest-only control group design. Terdapat dua kelas dalam penelitian ini yaitu kelas pertama disebut sebagai kelas eksperimen dan kelas kedua disebut sebagai kelas kontrol. Adapun sekolah yang menjadi tempat penelitian adalah di SMP Negeri 2 Singkawang kelas VII yang beralamat di Kelurahan Roban Kecamatan Singkawang Tengah. Populasi dalam penelitian ini adalah seluruh kelas VII SMP Negeri 2 Singkawang yang terdiri dari lima kelas yaitu VII A, VII B, VII C, VII D dan VII E yang berjumlah 147 siswa. Teknik pengambilan sampel pada penelitian ini dengan menggunakan teknik cluster random sampling. Adapun yang menjadi kelas eksperimen adalah kelas VIIC dan kelas kontrol adalah kelas VIIE.

Teknik analisis data yang digunakan dalam penelitian ini adalah analisis kuantitatif dengan statistika. Dalam penelitian ini akan diperoleh data kuantitatif sehingga untuk menganalisis data didapatkan dari pemberian tes motivasi menggunakan lembar angket akan dilakukan teknik statistik. Untuk memperoleh soal tes yang baik maka soal tes tersebut harus dinilai validitas, realiabilitas, tingkat kesukaran dan daya pembeda.

Untuk menjawab sub permasalahan pertama peneliti menggunakan uji mann whitney $u$ test karena salah satu data berditribusi tidak normal yaitu data kelas kontrol. Kemudian untuk menjawab sub permasalahan kedua menggunakan effect size. Dan untuk menjawab sub permsalahan ketiga dengan cara menghitung rata-rata motivasi belajar siswa untuk tiap indikator dilanjutkan dengan menghitung rata-rata seluruh indikator angket motivasi belajar siswa.

\section{RESULTS AND DISCUSSIONS}

\section{Kemampuan Pemecahan Masalah Matematis Siswa}

Hasil pengumpulan data selama penelitian diperoleh data hasil posttest (berupa skor) dari kelas yang diajarkan dengan model pembelajaran Problem Based Learning dengan pendekatan Saintifik untuk kelas eksperimen dan pembelajaran langsung untuk kelas kontrol terhadap kemampuan pemecahan masalah matematis siswa pada materi perbandingan. Penilaian kemampuan pemecahan masalah matematis siswa dinilai dari skor rata-rata kemampuan pemecahan masalah matematis siswa. Adapun soal posttest yang diberikan berbentuk tes kemampuan pemecahan masalah sebanyak dua soal dengan empat indikator yaitu: (a)Memahami masalah;(b)Merencanakan penyelesaianmasalah;(c)Melakukanperhitungan;(d)Memeriksa kembalihasil yang diperoleh.

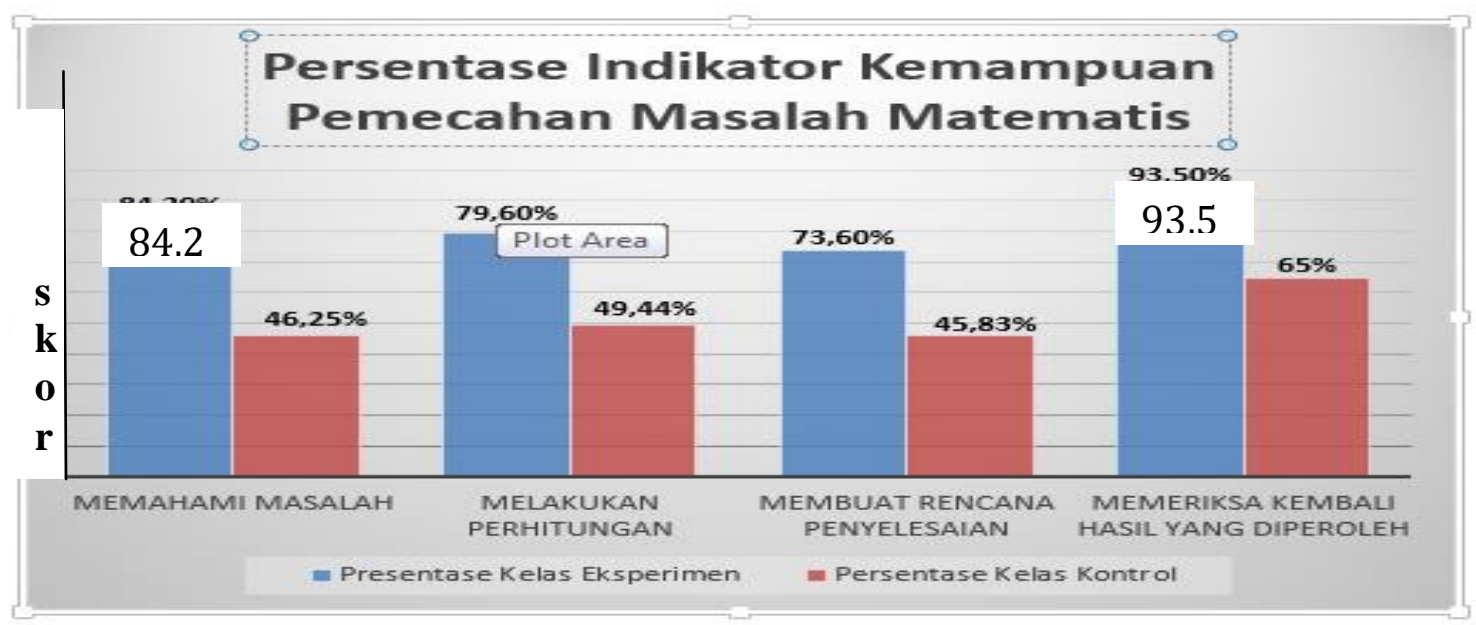

Gambar 1. Indikator kemampuan pemecahan masalah 
Dari Gambar 1 diketahui bahwa rata-rata indikator kemampuan pemecahan masalah matematis siswa kelas eksperimen lebih tinggi daripada rata-rata indikator kemampuan pemecahan masalah matematis siswa kelas kontrol. Selanjutnya secara keseluruhan rata-rata hasil posttest kemampuan pemecahan masalah matematis siswa kelas eksperimen dan kelas kontrol.

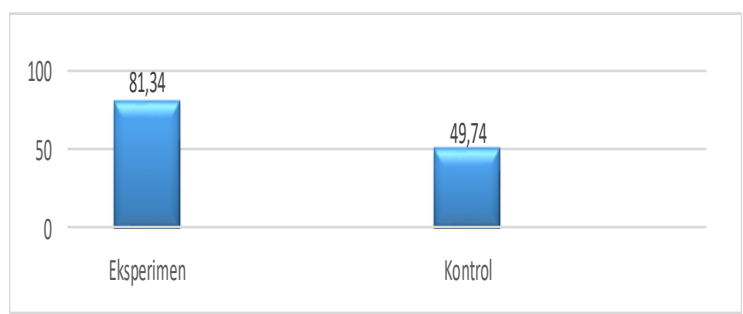

Gambar 2. Diagram Batang Nilai Rata-Rata Posttest Kelas Ekperimen Dan Kelas Kontrol

Gambar 1 dan 2 menunjukan bahwa secara deskriptif rata-rata posttest antara kelas kontrol dan kelas eksperimen berbeda, namun secara inferensial nilai tersebut belum tentu memiliki perbedaan yang signifikan. Untuk melihat perbedaan antara kelas yang menggunakan model pembelajaran Problem Based Learning (PBL) dengan kelas yang menggunakan model pembelajaran langsung (kelas kontrol) maka menggunakan uji-t dua sampel independen. Namun sebelumnya dilakukan uji normalitas dan uji homogenitas. Berdasarkan hasil perhitungan, untuk data posttest kelas eksperimen dan kontrol disajikan ada Tabel I sebagai berikut:

\begin{tabular}{|c|c|c|c|c|c|}
\hline $\begin{array}{l}\text { Kelom } \\
\text { pok }\end{array}$ & $\mathrm{N}$ & $\begin{array}{c}\text { Taraf } \\
\text { Signifi } \\
\text { kan }\end{array}$ & $\begin{array}{c}\chi^{2} \\
\text { Hitung }\end{array}$ & $\begin{array}{c}\chi^{2} \\
\text { Tabel }\end{array}$ & Kesimpulan \\
\hline $\begin{array}{l}\text { Eksperi } \\
\text { men }\end{array}$ & 27 & $5 \%$ & 5,019 & 9,488 & $\begin{array}{c}\text { Data Berdistribusi } \\
\text { Normal }\end{array}$ \\
\hline Kontrol & 30 & $5 \%$ & 28,4744 & 9,488 & $\begin{array}{c}\text { Data Berdistribusi tidak } \\
\text { Normal }\end{array}$ \\
\hline
\end{tabular}

Tabel I diketahui bahwa data posttest kelas eksperimen berdistribusi normal dan kelas kontrol berdistribusi tidak normal. Maka untuk mengetahui perbedaan penggunaan model pembelajaran PBL dengan pendekatan saintifik dan model pembelajaran langsung peneliti menggunakan uji Man Whitney U-Test. Adapun rekapitulasi hasil perhitungan perbedaan penggunaan model pembelajaran PBL dan model pembelajaran langsung terhadap kemampuan pemecahan masalah matematis siswa dapat dilihat pada Tabel II berikut.

Tabel II Rekapitulasi perhitungan uji mann whitney $u$ test

\begin{tabular}{ccccccc}
\hline Keterangan & $n_{1}$ & $n_{\mathbf{2}}$ & $\mathbf{U}_{\mathbf{i}}$ & $\mathbf{U}_{\mathbf{\Sigma}}$ & $\mathbf{E}(\mathbf{U})$ & $\operatorname{Var}(\mathbf{U})$ \\
\hline Skor & 27 & 30 & 4,5 & 816,5 & 405 & 3.915 \\
\hline $\mathbf{Z}_{\text {hitung }}$ & \multicolumn{7}{c}{$-6,4$} \\
\hline $\mathbf{Z}_{\text {tabel }}$ & \multicolumn{7}{c}{$-1,96$} \\
\hline
\end{tabular}

Tabel II di atas terlihat bahwa nilai $Z_{\text {hitung }}=-6,4$. Berdasarkan kriteria pengujian maka penggunaan model pembelajaran PBL dengan pendekatan Saintifik dan model pembelajaran langsung terhadap kemampuan pemecahan masalah matematis siswa dikatakan memiliki perbedaan apabila $Z_{\text {hitung }}<-Z_{\text {tabel }}$ atau $\mathrm{H}_{\mathrm{o}}$ ditolak, sebaliknya dikatakan tidak ada perbedaan penggunaan model pembelajaran PBL dengan pendekatan Saintifik dan model pembelajaran langsung terhadap kemampuan pemecahan masalah matematis siswa apabila $-\mathrm{Z}_{\text {tabel }} \leq \mathrm{Z}_{\text {hitung }} \leq \mathrm{Z}_{\text {tabel }}$ atau $\mathrm{H}_{\mathrm{o}}$ diterima. Diketahui $\mathrm{Z}_{\text {hitung }}<-\mathrm{Z}_{\text {tabel }}$ atau $6,4<-1,96$, maka Ho ditolak. Dapat disimpulkan bahwa terdapat perbedaan penggunaan model pembelajaran PBL dengan pendekatan Saintifik dan model pembelajaran langsung terhadap 
kemampuan pemecahan masalah matematis siswa pada materi perbandingan kelas VII SMP Negeri 2 Singkawang.

Perbedaan kemampuan pemecahan masalah matematis antara kelas eksperimen dan kelas kontrol disebabkan pada proses pembelajaran dengan model $P B L$ dengan pendekatan Saintifik memiliki tahapan-tahapan yang membuat siswa lebih aktif dan lebih dapat memahami materi. Hal ini disebabkan karena adanya keterkaitan antara model Problem Based Learning dengan pendekatan Saintifik dan kemampuan pemecahan masalah matematis siswa yaitu pada tahap stimulasi dimana masing-masing kelompok diberi kesempatan untuk mengamati LKK, dan tahap pemprosesan data siswa diminta untuk memecahkan masalah dan mengolah data yang terdapat dalam LKK secara kelompok. Hal ini dapat meningkatkan kemampuan siswa dalam memecahkan masalah dan mengembangkan kemampuan bepikirnya menghubungkan materi yang dipelajari dengan pengalaman mereka dalam kehidupan sehari-hari yang membuat mereka berfikir secara beralasan dan reflektif. Guru tidak sekadar memberikan pengetahuan kepada siswa, melainkan memfasilitasi siswa untuk membangun pengetahuannya sendiri sehingga siswa memiliki pemahaman yang lebih mantap terhadap materi perbandingan.

Hal yang sama juga diperkuat dengan hasil penelitian yang dilakukan oleh Widyaningrum (2016) yang menunjukkan bahwa pembelajaran matematika menggunakan model PBL pada hasil belajar siswa mengalami peningkatan mulai dari pree test, post test siklus satu sampai post test siklus dua yang sekaligus juga peningkatan kemampuan pemecahan masalah matematika. Hal ini dapat dikatahui dari rata - rata nilai siswa 44,74 (pre test), meningkat menjadi 52,63 (post test siklus 1) dan meningkat lagi menjadi 71,94 (post test siklus 2). Dapat disimpulkan bahwa model Problem Based Learning dengan pendekatan Saintifik berpengaruh signifikan terhadap kemampuan pemecahan masalah matematis siswa.

Selanjutnya untuk melihat seberapa besar pengaruh model pembelajaran PBL dengan pendekatan Saintifik terhadap kemampuan pemecahan masalah matematis siswa, maka digunakan rumus Effect Size. Adapun hasil perhitungan Effect Size dapat dilihat pada Tabel III sebagai berikut.

Tabel III Rekapitulasi hasil Effect Size

\begin{tabular}{ccccc}
\hline Kelas & $\begin{array}{c}\text { Nilai } \\
\text { Rata-rata }\end{array}$ & $\begin{array}{c}\text { Standar } \\
\text { Deviasi Kelas } \\
\text { Kontrol }\end{array}$ & ES & Kriteria \\
\cline { 1 - 2 } Eksperimen & 80,4 & 8,84 & 3,5 & $\begin{array}{c}\text { Pengaruhnya } \\
\text { Tinggi }\end{array}$ \\
\hline Kontrol & 49,4 & & & \\
\hline
\end{tabular}

Tabel III dapat dilihat bahwa hasil perhitungan Effect Size $=3,5$ dengan kriteria tinggi karena 3,5 berada pada $E S \geq 0,8$. Ini berarti model pembelajaran $P B L$ dengan pendekatan Saintifik memberikan pengaruh terhadap kemampuan pemecahan masalah matematis siswa yaitu sebesar 3,5 yang masuk pada kriteria tinggi.

\section{Motivasi Belajar Siswa}

Angket motivasi belajar siswa dalam penelitian ini merupakan angket yang hanya diberikan kepada siswa kelas eksperimen untuk mengetahui seberapa besar motivasi siswa dengan diterapkan model pembelajaran $P B L$ dengan pendekatan Saintifik. Angket motivasi belajar tersebut merupakan angket tertutup dan siswa hanya memilih satu jawaban dari 5 pilihan yang diberikan (sangat setuju, setuju, ragu-ragu, tidak setuju dan sangat tidak setuju) yang telah disediakan. Angket motivasi yang digunakan berupa pernyataan positif dan pernyataan negatif yang berjumlah 20 pernyataan dan terdiri dari 5 indikator motivasi belajar. 
Secara keseluruhan rata-rata motivasi belajar siswa baik dari pernyataan positif dan pernyataan negatif dapat dilihat pada Tabel VI berikut ini.

Tabel IV Rekapitulasi Hasil Angket Motivasi Siswa Untuk Seluruh Indikator

\begin{tabular}{lcl}
\hline Kategori & $\begin{array}{c}\text { Rata- } \\
\text { rata }\end{array}$ & Kriteria \\
\hline $\begin{array}{l}\text { Adanya dorongan dan kebutuhan } \\
\text { dalam belajar }\end{array}$ & 4,18 & Tinggi \\
\hline $\begin{array}{l}\text { Menunjukan perhatian dan minat } \\
\text { terhadap tugas-tugas yang diberikan }\end{array}$ & 4,17 & Tinggi \\
\hline Tekun menghadapi tugas & 4,03 & Tinggi \\
\hline $\begin{array}{l}\text { Ulet menghadapi kesulitan } \\
\text { Adanya hasrat dan keinginan berhasil }\end{array}$ & 4,23 & $\begin{array}{l}\text { Sangat } \\
\text { Tinggi }\end{array}$ \\
\hline \multicolumn{2}{c}{$\mathbf{4 , 1 6}$} & Tinggi \\
\hline
\end{tabular}

Dari Tabel IV dapat dilihat bahwa rata-rata motivasi belajar siswa untuk pernyataan positif dan negatif pada semua indikator berada pada kriteria tinggi dengan jumlah 27 siswa menghasilkan rata-rata keseluruhan siswa adalah 4,16 dengan kriteria tinggi karena berada pada kisaran $3,4<\bar{X} \leq 4,2$.

Tingginya motivasi belajar siswa kelas ekperimen pada penelitian ini dikarenakan pada model pembelajaran $P B L$ dengan pendekatan Saintifik, siswa tidak langsung diberikan hasil akhir dari penyelesaian, melainkan siswa dilatih untuk belajar menyelesaikan masalah dengan cara mereka sendiri melalui diskusi bersama teman sekelompoknya dengan bantuan guru sehingga menimbulkan keingintahuan mereka untuk bisa menyelesaikan masalah yang secara tidak langsung memotivasi keinginan siswa untuk belajar, misalnya pada salah satu tahapan Seperti halnya ada tahap pengumpulan data siswa diminta untuk mengumpulkan informasi dari berbagai sumber seperti buku secara berkelompok, sehingga membuat siswa ulet dalam menyelesaikan tugas.

Hal ini menunjukan tingginya mootivasi belajar siswa pada model Problem Based Learning dengan Pendekatan Saintifik. Dan sejalan dengan hasil penelitian Istiqomah (2013) yang menunjukkan bahwa motivasi dan hasil belajar siswa meningkat setelah diterapkan model Problem Based Learning pada siklus I $(52,63 \%)$ dan pada siklus II $(84,21 \%)$ meningkat hingga $31,58 \%$.

\section{CONCLUSION AND SUGGESTION}

Berdasarkan hasil penelitian dan pembahasan pada bab sebelumnya, penelitian yang dilakukan peneliti di MTS Al-Fatah Singkawang dapat disimpulkan yaitu sebagai berikut

1. Kemampuan koneksi matematis siswa dalam memecahkan masalah geometri berdasarkan tingkat berpikir Van Hiele di kelas VIII MTS Al-Fatah Singkawang, a) persentase kemampuan siswa dalam memecahkan masalah pada indikator 1 sebesar 66,67\% dengan kategori sedang, b) persentase kemampuan siswa dalam memecahkan masalah pada indikator 2 sebesar 26,11\% dengan kategori rendah, dan c) Persentase kemampuan siswa dalam memecahkan masalah pada indikator 3 sebesar $0,36 \%$ dengan kategori rendah

2. Kesalahan kemampuan koneksi matematis siswa yaitu; a) Indikator 1 kesalahan yang dilakukan pada tahap ini adalah siswa tidak mampu memahami masalah apa yang diketahui dan ditanyakan hanya lebih pada proses hasil jawaban. Salah memaknai soal, mengabaikan kondisi soal, kesaalahan konsep dan salah menggunakan rumus, b) Indikator 2 kesalahan yang dilakukan pada tahap ini yaitu kesalahan prosedur dan kesalahan dalam menggunakan rumus, dan c) Indikator 3 kesalahan yang dilakukan pada tahap ini yaitu kesalahan dalam mengubah bahasa sehari-hari kedalam bentuk matematika. 
3. Faktor penyebab siswa melakukan kesalahan kemampuan koneksi matematis yaitu; a) Fakta bahwa sebagian besar siswa ketidakmampuan siswa mencapai indikator yang pertama disebabkan oleh factor (siswa tidak mampu memahami masalah, siswa tidak mampu dalam memaknai soal, dan siswa tidak mampu dalam melakukan proses pengukuran dan penentuan suatu konsep atau memahami konsep), b)Fakta bahwa sebagian besar tidak mampu mencapai indikator yang kedua disebabkan oleh factor (Siswa tidak mampu dalam mengungkapkan ide-idenya yang ia miliki untuk menyelesaikan soal yang diberikan, siswa kurang teliti melihat hubungan-hubungan apa dari data yang ada, dan siswa mengalami kesulitan dalaam melakukan perhitungan), c) Fakta bahwa sebagian besar siswa tidak mampu mencapai indikator yang ketiga disebabkan oleh factor (Siswa tidak mampu dalam memaknai soal dan mengubahnya dalam bahasa sehari-hari kedalam bentuk matematika, siswa tidak mampu megubah $\mathrm{cm}$ ke dm, dan siswa tidak mampu membuat simpulan dari proses perhitungan dan penyelidikan yang telah dilaksanakan

\section{ACKNOWLEDGMENTS}

Berdasarkan kesimpulan di atas terdapat beberapa saran yang dapat penulis sampaikan pada penelitian ini sebagai berikut:

1. Bagi Guru

Guru sebaiknya perlu sesekali mengasah kemampuan koneksi matematis siswa, agar siswa dapat mengaitkan matematika dalam kehidupan sehari-hari ataupun dengan bidang studi lain dan siswa dapat mengetahui kaitan antar topik matematika. Siswa dapat sering diberikan contoh soal latihan dengan menggunakan kemampuan koneksi matematis, agar siswa bisa dan terbiasa untuk menyelesaikan soal yang memerlukan kemampuan koneksi matematis

2. Bagi Siswa

Siswa diharapkan agar lebih banyak mengulang kembali pelajaran yang sudah dipelajari, dan belajar untuk bisa fokus terhadap pelajaran tanpa mebuat keributan dan menggangu teman.

3. Bagi Peneliti

Peneliti diharapkan agar dapat menambah pengalaman dan menjadi masukan bagi peneliti lain untuk dapat dijadikan penunjang penelitian terhadap masalah yang sesuai dengan topik tersebut, serta untuk menambah wawasan baik dalam bidang penulisan maupun penelitian.

4. Bagi Peneliti Lain

Peneliti lain disarankan agar dapat melakukan penelitian lanjutan untuk mengetahui faktor yang menyebabkan siswa dengan kategori tinggi, sedang dan rendah, kemampuan koneksi dan belum mampu untuk menyelesaikan masalah kemampuan koneksi dengan baik.

\section{REFERENCES}

Amir, Muhammad Faizal. (2017). Analisis kesalahan mahasiswa PGSD Universitas Muhammadiyah Sidoarjo dalam meyelesaikan Soal Pertidaksamaan Linear. Jurnal Edukasi. Kajian Ilmu Pendidikan. 1(2), 131-146.

Lestari, k.. (2014). Implementasi Brain-Based Learning Untuk Meningkatkan Kemampuan Koneksi dan Kemampuan Berpikir Kritis Serta Motivasi Belajar Siswa SMP. Jurnal Pendidik. USINKA, 2(1), 36-46

Lestari, Kurnia Eka dan Yudhanegara, Mohammad Ridwan. (2015). Penelitian Pendidikan Matematika, Panduan Praktis Menyusun Skripsi, Tesis, dan Laporan Penelitian dengan Pendekatan Kuantitatif, Kualitatif, dan Kombinasi Disertai dengan Model Pembelajaran dan Kemampuan Matematis. Bandung: PT Refika Aditama.

Mulyana, E. (2003). Masalah Ketidaktepatan Istilah dan Simbol dalam Geometri SLTP kelas 1. Makalah FPMIPA UPI

Musriliani, dkk. (2015). Pengaruh Pembelajan Contextual Teching Learning (CTL) terhadap Kemampuan Koneksi Matematis Siswa SMP Ditinjau dari Gender. Jurnal Didaktik Matematika. 2( 2), 49-58. 
Mariyam, dkk. (2018). Pengembangan Kemampuan Pemecahan Masalah Matematis Siswa pada Materi Pertidaksamaan Linear Satu Variabel Melalui Model Problem Based Learning Berbantuan Modul. JPMI(Jurnal Pendidikan Matematika Indonesia). 3(2), 66-73.

Nawawi, Hadari. (2015). Metode Penelitian di Bidang Sosial. Yogyakarta: Gadjah Mada University Press.

National Council of Teacher of Mathematics (NCTM).(2000). Principles and Standars for School Mathematics. Virginia: Reston.

Nuriyah, Fajar E. (2015). Analisis Kesalahan Siswa dalam Menyelesaikan Soal Matematika Materi Pokok Persamaan dan Fungsi Persamaan Kuadrat pada Siswa Kelas x MIA SMA Negeri 2 Wonosari. Skripsi. Universitas Negeri Yogyakarta

Prihatiningtyas, Nindy C. \& Nurhayati. (2017). Penerapan Model Pembelajaran Means-Ends Analysis Untuk Meningkatkan Kemampuan Pemecahan Masalah Matematis Siswa. JPMI (Jurnal Pendidikan Matematika Indonesia), 2(1), 13-18.

Romli, Muhammad. (2016). Profil kemampuan koneksi matematis siswa perempuan SMA dengan kemampuan tinggi dalam menyelesaikan masalah matematika. Journal of mathematics education, science \& tehnology. 1(2), 145-157.

Sugiman. (2008). Koneksi Matematik dalam Pembelajaran Matematika di Sekolah Menengah Pertama. Jurnal Pendidikan Matematika. 4(1), 56-66.

Sundayana. (2014). Statistika Penelitian Pendidikan. Bandung: Penerbit Alfabeta

Warih, dkk. (2016). Analisis Kemampuan Koneksi Matematis Siswa Kelas VIII Pada Materi Teorema Phytagoras. In Prosiding Konferensi Nasioanal Penelitian Matematika dan Pembelajarannya (KNPMP 1). Diselenggarakan oleh Program Studi Pendidikan Matematika, UMS, 12 Maret 2016, (hal. 377-384). Muhammadiyah University Press. Diakses dari https://publikasiilmiah.ums.ac.id/hadle/2502/6526

Widarti (2013). Kemampuan Koneksi Matematis dalam Menyelesaikan Masalah Kontekstual Ditinjau dari Kemampuan Matematis siswa. Skripsi. Pendidikan Matematika STKIP PGRI Jombang.

Yuniawati. (2011). Penerapan Pembelajaran Matematika dengan Strategi React untuk meningkatkan kemampuan koneksi dan Representasi Matematis Siswa Sekolah Dasar. Jurnal Edisin Khusus No 2 